\title{
Presidential Leadership in Institutional Advancement: From the Perspective of the President and Vice President of Institutional Advancement
}

Received (in revised form): May 9, 2006

\section{Rhonda Sturgis}

Rhonda Sturgis is an adjunct faculty member with Saint Leo University. She holds an Ed.D. in Higher Education Administration from The George Washington University. Her career in higher education includes service as a Director of a University Campus and a teacher. In addition, Dr. Sturgis has worked in local government as a management analyst and deputy coordinator with a focus on strategic planning and management. She is a member of the Society of Human Resource Management, the American Society for Training and Development, the Higher Education Association, American Society for Public Administration and the International Virginia Emergency Management Association.

\section{Abstract \\ Since the establishment of higher education systems in the US the position of college and university president has evolved. In regards to fund-raising this position has changed dramatically with the creation of the vice president of institutional advancement. Over time these two positions have expanded the fund- raising function into a team effort. Within this team environment leadership is a key attribute to fund- raising success. For fund-raising to be successful the president must be a strong leader who is focused on teamwork, providing communication,}

\section{Author's Contact Address:}

Rhonda Sturgis

Adjunct faculty member 108 Eastwood Drive,

Newport News, VA 23602, USA.

Tel: 757-269-2902;

E-mail: rhonda.sturgis@saintleo.edu and working with the team to set goals and objectives. As the team relationship is so important, this study utilized the Team Performance Questionnaire (TPQ), by Dr. Riechmann, to explore the hypothesis that presidents and vice presidents of institutional advancement will have similar perspectives on presidential leadership as it relates to the fund-raising environment. The findings of this study provide interesting perceptions on presidential leadership in the fund-raising arena. By understanding these leadership perceptions the president and vice president can work toward overcoming misconceptions and develop a dynamic fund-raising team.

International Journal of Educational Advancement (2006) 6, 221-231. doi:10.1057/palgrave.ijea.2150019 
Keywords:

presidents, fund-raising, leadership

\section{Introduction}

Throughout history presidents have had an integral role in the leadership of the institution, especially as it relates to fund-raising. Over time with the creation and changing role of the development officer the fund-raising leadership of the president has become ambiguous. Today within the institutional advancement field the president and vice president of institutional advancement have varied roles that many times intertwine. These roles lead each to have different perspectives on the leadership role of the president within the institutional advancement environment. The purpose of this study was to determine how presidents are perceived in their leadership role relating to fund-raising by himself or herself and by the vice president of institutional advancement. Based upon the Team Performance Questionnaire the results of this study show that presidents and vice presidents have different perspectives on how effective presidential leadership is as it relates to fund-raising activities. This study begins by focusing on how the fund-raising roles have developed and intertwined between presidents and vice presidents of institutional advancement, how they have had to work as a team, and how the president must portray a leadership role that is conducive to a team environment. It then evaluates the current perception of presidential leadership from the viewpoint of presidents and vice presidents of institutional advancement and finally interprets the findings based upon the literature.

\section{Overview of Institutional Advancement Leadership}

\section{Changing roles of the president and vice president in institutional advancement}

The role of the president and vice president of institutional advancement have evolved, where both parties play an important role within the fundraising environment. Presidents have played a fundamental role in fundraising since the beginning of the American higher educational system. The original colonial colleges were created by various Protestant denominations. The president was a denominational minister who reported to the Board of Trustees, and had as one of their major responsibilities the identification of financial resources (Kauffman, 1980). With the beginning of the Revolutionary War, a reduction and then a total stoppage of funds from Great Britain made it more difficult for colleges to operate so presidents began to appeal to the general public for financial support. During this era presidents focused more on fund-raising issues than on educational leadership. As the US developed and became free from Great Britain institutional leaders realized the importance of government and state funding to increase revenue and placed a lot of emphasis on receiving these funds. By 1870, all 37 states had founded or laid the groundwork for establishing a land grant college and with the creation of so many institutions, state funding for the private sector decreased because they could not support them all (Rudolph, 1962). The reduction in government support again led presidents to focus on the general public for support. 
With the onset of World War I, fund-raising became a professional field, but the first development officers did not appear until the 1950s (Worth, 1993). After World War II, the creation of the GI Bill caused colleges to become overwhelmed with a higher student population, which created more financial problems. With more institutions, more students, and an increase in inflation a desire for a professional marketing strategy became essential with a refocus on the duties of the college president. Presidents were paying more attention to academic matters, public relations, budgets, and record keeping (Taylor, 1987). Most colleges and universities had to turn to professional staff to handle the growing demand of fundraising because it was no longer considered to be an adjunct duty. With the creation of permanent staff the position of the development officer began to emerge. This position became that of manager, and then eventually institutional leader, because the department was vital to the financial well being of the institution. Today the Vice President of Institutional Advancement sits alongside the Vice President of Academic Affairs, and the Vice President of Finance in the Chief Executive Offices cabinet and has a voice in matters of institutional policy (Worth and Asp, 1996).

The historical overview of fundraising within American higher education shows that Presidents and Vice Presidents have played an important role in fund-raising activities, which have changed overtime. Throughout history their roles and responsibilities have overlapped making it difficult to accomplish fund-raising activities without the support of each other and making it difficult to determine the leadership roles each member plays within this environment.

\section{Presidents' Role}

Today presidents are the leaders of their educational institutions. They are responsible for leading the college or university in defining and articulating the institutional mission, priorities, strategic planning, and goals (Kinnison and Ferrin, 1989). The president takes the lead in institutional policy and oversees the management of all activities and aspects of the institution, including fund-raising. Ultimately the president is the leader of the institution and is responsible for the organization's direction and success. From the fund-raising perspective the president defines priorities, sets goals, and explains the case to constituents. According to a study by Erikson (1997), presidents spend $20-35 \%$ of their time on fund-raising activities. The president should be the ultimate manager and decision maker of the fund-raising program, and the leader of the team of professional fund-raisers and volunteers. As the president delegates the operational responsibilities of fund-raising to the vice president of institutional advancement and typically supervises this officer, the president must ensure that a competent staff is in place to raise institutional funds (Ryans and Shanklin, 1986). The president sets levels of achievement and expectation for the development staff while supporting this staff in the performance of its functions. The president, then, supervises the development staff but delegates 
operational responsibility for fundraising to this staff while continuously evaluating staff performance against overall institutional goals (Patton, 1993). The president is the leader of the institution and must participate in fund-raising and perform duties that will create an environment that encourages revenue to be generated.

\section{Vice presidents' role}

The vice president for institutional advancement is the operational officer in charge of fund-raising under the supervision of the president while carrying out institutional goals. There is much debate among professionals in the field on the appropriate role of this vice president. From a review of higher education fund-raising literature four roles emerge. The first view perceives the vice president as someone who manages fund-raising efforts. In this perspective, the vice president focuses on tasks associated with management, organization, and direction of fundraising (Worth and Asp, 1996). As a study by Marcus (1989) indicated, development officers spend $50 \%$ of their time on management activities. This view sees the vice president as adjusting fund-raising goals to meet the institutional priorities as set by the president. The second view professes the vice president to be a researcher. In this view, primary responsibilities are to ensure adequate research of possible donors so that resources and time of others are not poorly planned and allocated. In this school although the vice president does the legwork by preparing correspondence and proposal, generating fund-raising ideas, motivating staff, keeping files, preparing reports, and mapping fund-raising calls, records, mailing lists, and acknowledgements (Patton, 1993). Ultimately, the vice president causes a solicitation, but remains at a distance from the actual process (Worth and Asp, 1996). The third view identifies the vice president as an activist in the fund-raising solicitation itself. In a dissertation by Crawford, he found that development officers devoted the greatest portion of their time to meeting donors (Crawford, 1976). As stated by Worth and Asp (1996), those who prescribe to this view feel that direct solicitation is the vice president's primary role. Finally, the fourth view focuses on the vice president as a leader within the institution. In this perspective, the vice president must be a member of the president's cabinet and involved in institutional policy development. It is important that the vice president play a leadership role so that fund-raising activities are taken into consideration and aligned with the institution's strategic plan (Kinnison and Ferrin, 1989). There is much debate about the role of the vice president of institutional advancement, which originates from the creation of the position. No matter the view it is evident that the vice president is ultimately responsible for the overall fund-raising efforts.

\section{Teamwork of president and vice president of institutional advancement}

Over time the president's and vice president's role in relation to fundraising has developed and changed. This change has lead to much debate on what functions a president and vice president should have within the 
fund-raising arena. Although there are a variety of views on the role and responsibility of each it is clear that they must work together as a team to make fund-raising successful.

Teamwork occurs in a situation such as this where members are performance-dependent upon each other (Buchholz and Roth, 1987). Although the literature from professionals on the nature of these interactions may vary in degree, they agree that high level and quality interactions are vital to fund-raising success. With regards to fund-raising, the relationship between the president and vice president of institutional advancement is mutually dependent. Kinnison and Ferrin (1989) promote that the president and vice president must desire a relationship, understand their specific roles, work diligently within their roles, have agreed upon goals, and be mutually supportive. The vice president must work with the president's energies, attention, and schedule to achieve success. Vice presidents do this by ensuring research is done and that the president only sees potential donors necessary to major gift giving (Whittier, 1981). Even though a vice president must be an expert in courting donors and making solicitations, nothing can substitute for a request from the president for truly major gifts. Thus, the president is dependent upon the vice president for donor preparation, and the vice president is dependent upon the president for strategic guidance of the fund-raising function and the most important solicitations. In the literature, the fund-raising roles, responsibilities, and relationships that exist between the president and vice president of institutional advancement are distinct yet intertwined. Each entity plays a vital, yet mutually dependent role in institutional fund-raising success requiring assistance from each other. They must work together to ensure a coherent theme throughout the fund-raising process or it will eventually fall apart. Success in fundraising is a team effort, because it enhances the fund-raising performance and provides results (Carlson and Clarke, 2000). Owing to the nature of the fund-raising environment and its creation it is imperative that the president and vice president of institutional advancement work together as a team to make fundraising successful.

\section{Presidential team leadership attribute}

The leadership attribute is an important quality of a leader within a team environment. It is imperative as the leader of the institution and of the overall fund-raising department that the president be a strong leader within the team environment. A leader must model high standards, integrity, and have full and open communication. The leader must provide a vision and communicate it. Clear performance measures must be set and monitored by the leader with individual rewards and team contributions. The leader must involve members in decisions affecting the team and publicly support the team in its decisions. Strong leadership serves as the seat of the team's identity. The team leader must be flexible and encourage participation in leadership. This is definitely important to a relationship such as the president and vice president share. As stated above, the vice president also 
plays a leadership role within the fund-raising environment and must be encouraged to participate in decision-making. As the leader, the president should encourage the team to work out goals and plans that meet the established purpose and allow them to evaluate results Buchholz and Roth (1987). Good leaders coach, scout resources, ask questions and lead the team by support only. The fundraising team must set goals that align with the institutions strategic plan and allow them to monitor their performance, while the president supports them in their daily operations. The president and vice president have intertwined roles and many times leadership of the team should change with the task because this management environment is a shared function. To be an effective leader the president should work with the fund-raising team to make tough choices, deal with the most complex problems, and take corrective action when things get off track (Zegner et al., 1994). Team leadership is important for teams to be successful, because in the fund-raising environment with the president and vice president having such intertwined roles they must work together to bring in funds. The president must be a leader of the institution and the overall direction of the fund-raising environment, but the vice president must be involved in making many leadership decisions that are best for the institutional advancement environment. If the president has effective team leadership skills, the fund-raising team will evolve to a leadership structure that is flexible, task driven, and supportive of goals.

\section{Conclusion}

The history of fund-raising has evolved to an environment where the president and vice president must operate as a team to bring funds into institutions. Only by working as a team can true fund-raising success be accomplished. For the team to be successful it must have a strong leader who is focused on promoting teamwork, providing communication, and working with the team to set goals and objectives.

Owing to the necessity of strong team leadership this paper focuses on the perceived leadership abilities of the president.

\section{Methodology}

Institutional advancement professionals advocate a team relationship between the president and vice president in relations to fund-raising efforts. Within this team environment the president must emerge as a leader who is able to communicate well, provides direction, and involves the vice president and other members in decisions affecting the team. Through the use of the Team Performance Questionnaire this study explored the hypothesis that presidents and vice presidents of institutional advancement will have similar perspectives of presidential leadership as it relates to the fund-raising environment (Riechmann, 1998). The methodology section will address the population and sample, the instrument utilized and the data collection process.

\section{Population and Sample}

The population for this study was 156 private baccalaureate I colleges and universities as classified by the Carnegie Classifications (1994). The classification lists contains all colleges 
and universities in the US that are degree granting and accredited by an agency recognized by the US Secretary of Education.

For the purpose of this study, it was important to ensure that these institutions had fund-raising programs. This is because the study was specifically evaluating the leadership perspective of the president within the team environment in relation to fundraising activities. The Voluntary Support for Education was compared against the colleges and universities selected for this study. Of the 156 institutions identified by the Carnegie Classification, $132(85 \%)$ responded to the 2001 Voluntary Support for Education Survey. For the purpose of this study, all 132 institutions were given the opportunity to participate by completing the questionnaire.

\section{Instrumentation}

The study used Team Performance Questionnaire created by Dr. Donna Riechmann. This questionnaire was developed specifically to reveal the team relationship, by measuring attributes, among team members. These attributes are goals and results, collaboration and involvement, competencies, communication processes, emotional climate, and leadership. This instrument was utilized since the team relationship between the president and vice president is the focus of this study. Although there are several attributes that make up a successful team environment, only the leadership attribute was utilized in this study. For the purpose of her instrument, Riechmann defined the leadership attribute to be where the member in charge models high standards, integrity, and full and open communication. The leader is the one who provides a vision and communicates it. Clear performance expectations are set and monitored, with individual rewards and team contributions. Leadership involves members in decisions affecting the team and publicly supports team decisions (Riechmann, 1998).

The questionnaire consisted of 32 team attribute questions, with seven specifically relating to the leadership perspective. The questions were to be answered on a 5-point scale ( 1 = strongly disagree, 2 = disagree, $3=$ neither agree nor disagree, $4=$ agree, $5=$ strongly agree). For the purpose of this study, only the seven relating to the leadership perspective were utilized. These seven items touch on leadership issues such as integrity, communication, expectations, performance, rewards, team contributions, and decision-making.

Dr. Riechmann complied pre-test data for the instrument to determine validity and reliability of the questionnaire. To ensure validity Riechmann organized a panel of five experts in team leadership and education to assess the questionnaire. They reviewed it independently, and each confirmed that the items captured the content domain of team performance. All experts verified that the items in the subscales also adequately reflected the content domain. Riechmann also performed a factor analysis on the team performance questionnaire using a varimax rotation. In the initial factor analysis of 40 items, eight were removed because they were redundant or confusing. In the final factor 
analysis, the remaining 32 were organized into the six attributes, with one of these being leadership (Riechmann, 1998).

Reliability was tested on the team performance questionnaire by collecting data form nine teams with 44 total respondents. Test-retest correlations by team, over a nonspecified time, for each subscale ranged from 0.71 to 0.90 , making them consistent. Riechmann determined from a combination of results that internal consistency was high for the team performance questionnaire. Data were collected from 183 respondents and Cronbach's coefficient alpha produced results ranging from 0.77 to 0.89 for the six subscales. From the test performed by Riechmann it was determined that the team performance questionnaire was adequately valid and reliable in measuring team relationships and evaluating specifically the leadership attribute addressed in this study (Riechmann, 1998).

\section{Data collection}

The data collection process began by collecting all the contact information for each institution. Institutional websites were utilized to gather information on presidents and vice presidents within each of the 132 institutions. Once addresses and names were established a notification letter was sent to each individual. This letter described the study, its utility, and methodology behind the institution and respondent selection. One week later the questionnaire packet was mailed. This consisted of a cover letter, a consent form, the questionnaire, and a self-addressed envelope. A deadline date of two weeks was given for returning the questionnaire, and then a post card was sent to all possible respondents. The post card served as a thank you for those who had responded and a reminder for those who had not. When an additional two weeks passed questionnaire package was sent to all who had not responded. Finally telephone calls were made to contact institutions that had not been heard from. After all the data was collected representatives from 56 $(42 \%)$ of the 132 institutions responded to the survey.

\section{Results}

This quantitative investigation was guided by the research hypothesis that presidents and vice presidents of institutional advancement will have similar perspectives of team leadership as performed by the president in relation to fund-raising efforts. For the purpose of this study, a one-way ANOVA compared the mean survey responses of presidents $(n=28)$ and vice presidents $(n=44)$ for the leadership attribute. The results of the leadership attribute had significant differences at the 0.05 level, $(p=0.025$, see Table 1) which results in rejecting the hypothesis for the purpose of this study. The assumptions of the ANOVA were satisfied. For all tests normality was met by sufficient sample size; equality of variance was met by nonsignificant Levene's test for equality of variance. Despite the inability to randomly assign subjects to the level of the independent variable the assumption of independence was considered met because the Games Howell tests, customarily used with unequal sample sizes, is exact when 
Table 1: Leadership attribute based on job title

\begin{tabular}{lccccc}
\hline Title & $n$ & $M$ & SD & F & $p$ \\
\hline $\begin{array}{l}\text { Leadership } \\
\quad \text { President }\end{array}$ & 19 & 4.83 & 0.82 & 3.24 & $0.03 *$ \\
$\quad$ Vice president & 42 & 4.17 & 0.80 & & \\
\hline
\end{tabular}

${ }^{a}$ For post hoc tests: presidents >vice presidents.

"Indicates significant at $\alpha=0.05$.

One way ANOVA with Games-Howell post hoc tests.

sample sizes are unequal, such as in the case of this analysis (Jones, 2004).

\section{Analysis and interpretations}

It is evident from the results that the president and vice president have different perspectives of presidential leadership as it relates to the fundraising environment. Presidents had significantly (0.03) higher mean $(M=4.83)$ scores than vice presidents $(m=4.17)$. This finding is understandable when considering the intertwined roles of the president and vice president within the fund-raising environment.

Based on this finding it can be interpreted from the literature that presidents might believe that their team members work well together, share information and ideas freely and honestly, make full use of each person's competencies while drawing on each other's strengths, and are competent in their abilities. As the organizational leader, presidents have perhaps overall satisfaction with the competencies of fund-raising efforts by team members. It can be speculated that presidents viewed themselves as demonstrating high levels of integrity, setting clear expectations for individuals and the team, while keeping everyone on the team informed and involving everyone in the decision-making process. Building from the survey responses, it is possible to surmise that the presidents saw themselves as leaders who confronted performance problems, while rewarding superior performance and appreciating members' contributions. Again, in the context of the literature, such presidents, more so than the vice presidents, may think they possess flexibility and encourage participation in leadership, where open communication and information sharing is of utmost importance. Based on the survey items, perhaps these presidents think they do a good job of providing and communicating the institutional fund-raising vision, while supporting the fund-raising team where needed.

On the other hand, the difference between the presidents and vice presidents scores may suggest that these vice presidents are not be as likely to view team members in such lights. As the leader of fund-raising efforts, it may be that the vice presidents suspect team members were not as fully functioning in fund-raising as they could be. Perhaps the vice presidents are tougher critics, have higher expectations of presidential leadership, or are expressing a frustration that due to the diversity of areas to which a president must provide attention, fund-raising leadership does not get as much as the vice president would desire. This reinforces the notion that even in competent teams, vice presidents and presidents may be able to work effectively together while providing disparate assessments of the team's performance. This disparity may be a 
positive instead of a negative. These vice presidents may simply have higher goals for future fund-raising and see the future as promises yet fulfilled while presidents provided survey responses based on the assessment of missions accomplished. As more directly involved the vice president may be more aware of difficulties or details that do not surface at the level of the president. In either interpretation, the presidents and vice presidents assess the competencies of the fund-raising team differently.

The data showed that the presidents as a group had significantly (0.03) higher mean $(m=4.83)$ scores than did the vice presidents $(m=4.17)$ as a group in relation to the leadership attribute. Vice presidents' results showed that presidents are not as strong in their leadership abilities when it comes to fund-raising efforts as perceived by the presidents. This could be due to the fact that vice presidents of institutional advancement have as their main focus the bringing of funds into the institution, whereas presidents have several other responsibilities in addition to fundraising. Although presidents care about fund-raising efforts their main goals lie in the overall organization, not just the fund-raising aspect, which could cause them not to be as knowledgeable as the vice president on fund-raising details or to be overly positive. In addition, their role as president would suggest that they are more adept at putting a positive spin on everything. Or perhaps, it is simply a part of the role of the president to be ever optimistic and positive and this alone may account for the scoring disparities.

\section{Recommendations and Conclusion}

\section{Recommendations for future research}

This study has provided a starting point for president and vice presidents as it relates to presidential leadership abilities within the fund-raising arena. Although interesting facts emerged future research should provide a stronger focus on what causes these actual perceptions, allowing both entities to come to some better understanding of what causes this significant difference. A more detailed survey, personal interviews, or preferably both could be utilized in future research opportunities.

\section{Recommendations for future practice}

Rejecting the hypothesis that presidents and vice presidents both perceive that presidents have strong team leadership skills as it relates to fund-raising efforts has implications for future practice. It provides a much-needed perspective on actual perceived leadership of presidents in the fundraising environment. This study brings awareness to both presidents and vice presidents of institutional advancement on the perceived leadership role the president has in fund-raising activities. By being aware of this perception presidents and vice presidents may be able to come to an understanding of each other's concerns and roles within the fund-raising environment. Working together to possibly address these perceptions both parties can come to an understanding of what leadership is actually needed and provided. 


\section{Conclusion}

This study has provided an insight to presidential leadership that has previously been overlooked within the fund-raising environment. By realizing that the president and vice president perceive presidential team leadership differently they can begin to work towards building a better fund-raising team with this understanding. With more detailed research a better foundation will develop allowing these entities to be focus of creating a dynamic fund-raising team with excellent presidential leadership.

\section{References}

Buchholz, S. and Roth, T. (1987), "Creating the High Performance Team," John Wiley \& Sons, Inc., New York, NY.

Carlson, M. and Clarke, C. (2000), "Team-Based Fundraising Step By Step: A Practical Guide to Improving Results Through Teamwork," JosseyBass Publishers, San Francisco, CA.

The Carnegie Classification of Institutions of Higher Education (1994) The Carnegie Foundation for the Advancement of Teaching, Menlo Park, CA.

Crawford, T.R. (1976), "The role of the chief development officer as perceived by presidents and chief development officers at selected institutions of higher education," Dissertation Abstract International (UMI No. 7712540).

Erikson, J.H. (1997), “The Role of Public University Presidents in the Development Process," University of California, Unpublished Study.

Jones, J. (2004), "Scheffe' and Tukey Tests Lecture Notes," University of Virginia, Unpublished Notes.

Kauffman, J.F. (1980), "At the Pleasure of the Board: The Service of the College And
University President," American Council on Education, Washington, DC.

Kinnison, W.A. and Ferrin, M.J. (1989), "The three-party relationship", in J.W. Pocock (eds.) Fund-Raising Leadership: A Guide for College and University Boards," Association of Governing Boards of Universities and Colleges, Washington DC, pp. 57-61.

Marcus, S.E. (1989, March), "Career and position profile of chief development officers at doctoral universities," Dissertation Abstract International, (UMI No. 8823821).

Patton, S.L. (1993), "The roles of key individuals", in M.J. Worth (eds.) Educational Fund Raising Principles and Practice," American Council on Education and the Oryx Press, Phoenix, AZ, pp. 51-56.

Riechmann, D. (1998), “Team Performance Questionnaire," Jossey-Bass Publishers, San Francisco, CA.

Rudolph, F. (1962), "The American College and University, A History," The University of Georgia Press, Athens, GA.

Ryans, C.C. and Shanklin, W.L. (1986), "Strategic Planning, Marketing and Public Relations, and Fund-Raising in Higher Education: Perspectives, Readings, and Annotated Biography," Scarecrow Press, Metuchen, NJ.

Taylor, B.E. (1987), “Working Effectively with Trustees: Building Cooperative Campus Leadership," ASHE-ERIC Higher Education Report, No. 2, Association for the Study of Higher Education, Washington, D.C.

Whittier, S.J. (1981, April), "How much access? The chief development officer's relationship with trustees," CASE Currents, 7, 22-24.

Worth, M.J. (eds.) (1993), "Educational Fund Raising Principles and Practice," American Council on Education and the Oryx Press, Phoenix, AZ.

Worth, M.J. and Asp, J.W. II (1996, February), "Salesperson, catalyst, manager, and leader: to be a better fundraiser, you need to balance many facets of the job. Here are four ways development experts view your current role," CASE Currents, 22, 24-28.

Zegner, J.H., Musselwhite, E., Hurson, K. and Perrin, C. (1994), "Leading Teams: Mastering the New Role," Business One Irwin, Homewood, IL. 